\title{
Diagnostic Accuracy of Paediatric Skull Radiograph Versus Whole Skeletal Survey in Skeletal Dysplasias And Dysostoses in High Risk Groups
}

\author{
Devimeenal Jagannathan ${ }^{1}$,Chirtrarasan Paraman $^{2}$,Kanagasabai \\ Ramanathan ${ }^{3}$,Sudhir Nagarajan ${ }^{4}$ \\ I'Professor,Head Of The Department,Department Of Radio-Diagnosis,Government Kilpauk Medical College- \\ Chennai-India) \\ ${ }^{2}$ (Associate Professor, Department Of Radio-Diagnosis, Government Kilpauk Medical College- Chennai-India) \\ ${ }^{3}$ (Assistant Professor, Department Of Radio-Diagnosis, Government Kilpauk Medical College-Chennai-India) \\ 4(Resident, Department Of Radio-Diagnosis, Government Kilpauk Medical College-Chennai-India)
}

\begin{abstract}
The objective of this study was to evaluate the diagnostic value of skull radiograph alone in young children in screening of skeletal dysplasias and dysostoses in comparison with whole skeletal survey. It is a retrospective study which includes 1000 high risk children who undergone whole skeletal survey. 20 patients were diagnosed as dysplasia/dysostoses out of which 18 patients had skull abnormalities. The sensitivity, specificity, positive predictive value and negative predictive value for skull Xray alone was $90 \%, 100 \%, 100 \%$ and $99.8 \%$ respectively in making correct diagnosis.Two patients who was diagnosed as chondrodysplasia punctata had no skull abnormalities. In high risk, children rather than doing whole skeletal survey as a routine examination, skull Xray can be done initially as screening tool and in case of abnormal findings or strong clinical suspicion of dysplasias associated with normal skull, rest of the skeletal survey can be considered. This approach will reduce effective radiation(E) dose for those children who are undergoing repeated exposures.

Keywords : Dysplasia/dysostoses, High risk children, skull Xray, whole skeletal survey
\end{abstract}

\section{Introduction}

Skeletal dysplasias are heterogenous group of bone disorders characterized by intrinsic disturbances in bone growth and structure that produce wide spectrum of clinical and radiological manifestations and often have a genetic basis and their phenotype continues to evolve throughout life. [1] Skeletal dysplasias differ from dysostoses which are congenital malformations of one or more bones which are phenotypically static and are due to abnormal blastogenesis in utero. The overall prevalence of this group has been reported as 2.3-7.6 cases per 10000 births in various studies. [1] The diagnosis of skeletal dysplasia depends on a combination of history, clinical examination, radiological evaluation and genetic and biochemical tests. Skull radiographs are obtained as a part of the diagnostic work-up for skeletal dysplasias and dysostoses along with whole skeletal survey. Skeletal dysplasias usually manifest with diffusely increased or decreased density or focal decreased density in skull radiograph. [2] Several studies have been done to identify the prevalence of skeletal dysplasias and dysostoses in various groups using whole skeletal survey, but none of those studies focussed on the use of skull radiograph alone as a screening tool for these conditions. Further, a previous study shows radiation exposure in young children for skull radiograph was $20 \mu \mathrm{Sv}$ (AnteroPosterior(AP) and lateral view) compared to whole skeletal survey which was $150 \mu \mathrm{Sv}$. [3] Hence we conducted the retrospective study to evaluate the diagnostic value of skull radiograph compared to whole skeletal survey as a screening tool for these conditions.

\subsection{Patients and Methods}

\section{Materials And Methods}

Retrospective study done in the Department of Radio-Diagnosis and Paediatrics, Government Kilpauk Medical College, Chennai, India for a period of two years from November 2014 to October 2016. The study population includes 1000 high risk children who came to the hospital \& underwent whole skeletal survey during the study period. High risk children include those with history of antenatal polyhydramnios, stillbirths/ malformations in siblings and relatives, consanguinity and maternal age more than 35 years.

\subsubsection{Radiological evaluation:}

The radiological evaluation consists of a set of radiographs which include- Skull (AP and lateral), Thoracolumbar spine (AP and lateral), Chest (AP), Pelvis(AP), One upper limb (AP) and Left hand (AP)(for bone age)The images were retrieved from the PACS workstation (Mediff technologies) and analysed by a 
radiologist with 10years experience in pediatric radiology. The skull radiographs and the whole skeletal survey including the skull were read separately by same radiologist.

The presence or absence of following features were analysed during the evaluation of the radiographs; In skull, diffusely increased or decreased density or focally decreased density, microcephaly or macrocephaly, abnormal shape and associated abnormalities. Spine can show flattening or decreased height of the vertebral body, abnormal vertebral hooking or beaking \& interpedicular distance. Abnormalities seen in the appendicular skeleton include the type of limb shortening i.e rhizomelic, mesomelic, acromelic or micromelic, location of abnormality i.e epiphyseal, metaphyseal or diaphyseal or more than one location. Additional features like altered shape of the bones in the pelvis and hand were looked for during the evaluation. All the suspected cases were subjected for biochemical and molecular tests for the confirmation of diagnosis.

\subsection{Statistical analysis}

The collected data were analysed with IBM.SPSS statistics software 23.0 Version. To describe about the data descriptive statistics, frequency analysis, percentage analysis, the Sensitivity, Specificity, PPV and NPV were used to compare the skull with whole skeletal survey.

\section{Results}

Figure 1. High risk children (Percentage distribution of various risk factor, $\mathrm{n}=1000$ )

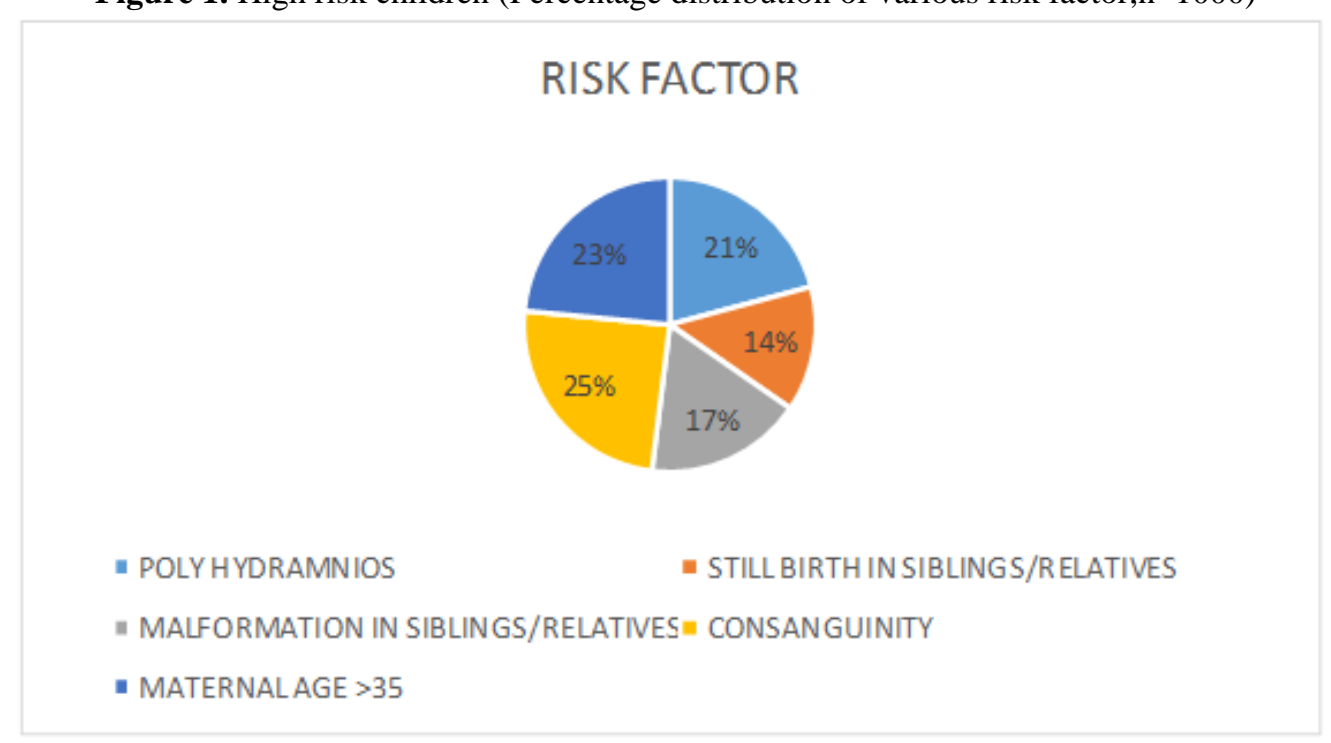

Figure 2. Age and sex demographics

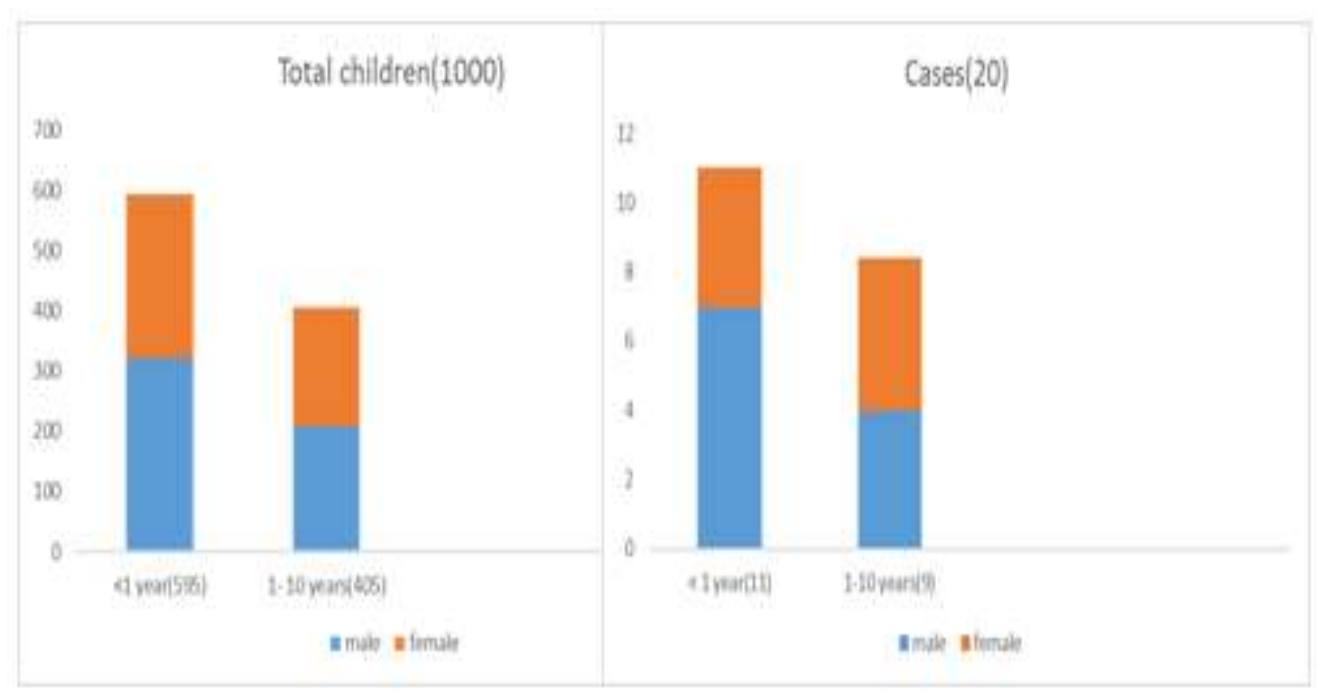


Age and sex distribution of high risk children screened and diagnosed cases. Out of 1000 children 595 were less than 12 months (323 male and 272 female) and remaining 405 were between 1 to 10 years (209 male and 196 female) and in 20 cases 11 were less than 12 months ( 7 male and 4 female) and remaining 9 cases were between 1 to 10 years ( 4 male and 5 female). Fig.(2)

Table 1. Skull radiograph findings and diagnosis( $(\mathrm{n}=18)$

\begin{tabular}{|c|c|c|}
\hline Diggrois & Caga & Findings \\
\hline Achondroplasis & 3 & 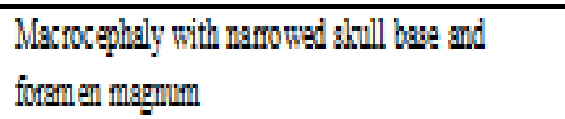 \\
\hline Chondroattodamal dysplaxia & l & Teth sbrom alitian (Dyplastic teth) \\
\hline Spondyloxpiphweal dyoplasia & 2 & Dolichocephaly \\
\hline Ottegenasis inperfecta & 2 & Density diffuely dxcresed and Platybsia \\
\hline Pylnodyoutodis & l & $\begin{array}{l}\text { Density diffusely incrass di, obtuse angle in } \\
\text { mandible, wide open fortanelle and womian bonas }\end{array}$ \\
\hline Ottoptiodis & l & Dansity diffuely incress is base of thull \\
\hline Cleidoramial dyplasia & l & Wownisn bonss with nomal mandible \\
\hline Hixler's & $\mathrm{T}$ & I shapat onlla and fuarocephaly \\
\hline Magations & l & Nominal walla with macocophaly \\
\hline Tumat? & $\bar{l}$ & Difus ely decresed density \\
\hline Apat's & $\mathrm{T}$ & Torer shaped shull \\
\hline Cariobyototois & l & Foxilly dereased density and coppes batten atrill \\
\hline Down's & $\bar{l}$ & Microcaphaly \\
\hline Pfififer's & $\overline{1}$ & 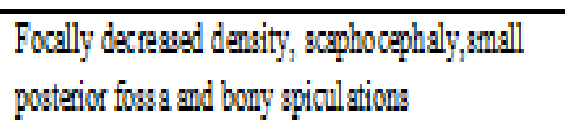 \\
\hline
\end{tabular}


Table 2. Whole skeletal survey findings and diagnosis( $\mathrm{n}=20)$

\begin{tabular}{|c|c|c|c|c|c|c|c|}
\hline \multirow[t]{2}{*}{ Diagnosis } & \multirow{2}{*}{$\begin{array}{l}\text { No. } \\
\text { Of } \\
\text { cases }\end{array}$} & \multirow[t]{2}{*}{ Skull findings } & \multirow{2}{*}{$\begin{array}{l}\text { Spine + chest } \\
\text { findings }\end{array}$} & \multirow{2}{*}{$\begin{array}{l}\text { Pelvic } \\
\text { abnormalities }\end{array}$} & \multirow[t]{2}{*}{ Hand } & \multicolumn{2}{|c|}{ Appendicular skeleton } \\
\hline & & & & & & $\begin{array}{l}\text { Type of } \\
\text { limb } \\
\text { shortening } \\
\end{array}$ & Location \\
\hline Achondroplasia & 3 & $\begin{array}{l}\text { Macrocephaly } \\
\text { with narrowed } \\
\text { skull base and } \\
\text { foramen magnum }\end{array}$ & $\begin{array}{l}\text { Narrow } \\
\text { interpedicular } \\
\text { distance, } \\
\text { bullet shaped } \\
\text { vertebral body }\end{array}$ & $\begin{array}{l}\text { Champagne- } \\
\text { glass } \\
\text { appearance, } \\
\text { squaring of } \\
\text { iliac wings }\end{array}$ & $\begin{array}{l}\text { Trident } \\
\text { hand }\end{array}$ & Rhizo-melic & $\begin{array}{l}\text { Metaphyseal } \\
\text { splaying + }\end{array}$ \\
\hline $\begin{array}{l}\text { Chondrodysplasia } \\
\text { punctate }\end{array}$ & 2 & \multicolumn{5}{|c|}{ Normal } & $\begin{array}{l}\text { Epiphyseal } \\
\text { stippling }\end{array}$ \\
\hline $\begin{array}{l}\text { Chondroectodermal } \\
\text { dysplasia }\end{array}$ & 1 & Dysplastic teeth & $\begin{array}{l}\text { Spine normal, } \\
\text { bell shaped } \\
\text { chest, } \\
\text { cardiomegaly }\end{array}$ & $\begin{array}{ll}\text { Flared iliac } \\
\text { wings, } \\
\text { triradiate } \\
\text { acetabula }\end{array}$ & $\begin{array}{l}\text { Postaxial } \\
\text { syndactly }\end{array}$ & $\begin{array}{l}\text { Acro- } \\
\text { mesomelic }\end{array}$ & Nil \\
\hline $\begin{array}{l}\text { Spondyloepiphyseal } \\
\text { dysplasia }\end{array}$ & 2 & Dolichocephaly & Platyspondyly & normal & normal & nil & $\begin{array}{l}\text { Epiphyseal } \\
\text { irregularity }\end{array}$ \\
\hline $\begin{array}{l}\text { Osteogenesis } \\
\text { imperfecta }\end{array}$ & 2 & $\begin{array}{l}\text { Density diffusely } \\
\text { decreased and } \\
\text { Platybasia }\end{array}$ & \multicolumn{5}{|c|}{ Cod fish vertebrae, multiple fractures with exuberant callus } \\
\hline Pyknodysostosis & 1 & $\begin{array}{l}\text { Density diffusely } \\
\text { increased, obtuse } \\
\text { angle in } \\
\text { mandible, wide } \\
\text { open fontanelle } \\
\text { and wormian } \\
\text { bones }\end{array}$ & Nil & $\begin{array}{l}\text { Shallow } \\
\text { acetabulae }\end{array}$ & $\begin{array}{l}\text { Acro- } \\
\text { osteolysis }\end{array}$ & Nil & Nil \\
\hline Osteopetrosis & 1 & $\begin{array}{l}\text { Density diffusely } \\
\text { increased i.e base } \\
\text { of skull }\end{array}$ & $\begin{array}{l}\text { Sandwich } \\
\text { vertebra }\end{array}$ & \multicolumn{2}{|c|}{ Bone within bone appearance } & Nil & Nil \\
\hline $\begin{array}{l}\text { Cleidocranial } \\
\text { dysplasia }\end{array}$ & 1 & $\begin{array}{lr}\text { Wormian } & \text { bones } \\
\text { with } & \text { normal } \\
\text { mandible } & \end{array}$ & $\begin{array}{l}\text { Absent } \\
\text { clavicles }\end{array}$ & $\begin{array}{l}\text { Widened } \\
\text { symphysis } \\
\text { pubis }\end{array}$ & $\begin{array}{l}\text { Accessory } \\
\text { epiphysis at } \\
2^{\text {nd }} \\
\text { metacarpal } \\
\end{array}$ & Nil & Nil \\
\hline Hurler's & 1 & $\begin{array}{l}\mathrm{J} \text { shaped sella and } \\
\text { macrocephaly }\end{array}$ & $\begin{array}{l}\text { Antero } \\
\text { inferior } \\
\text { beaking, } \\
\text { paddle shaped } \\
\text { ribs }\end{array}$ & $\begin{array}{l}\text { Sloping of iliac } \\
\text { wings with } \\
\text { shallow } \\
\text { acetabula }\end{array}$ & $\begin{array}{l}\text { Proximal } \\
\text { pointing of } \\
\text { metacarpals }\end{array}$ & Nil & Nil \\
\hline Morquio's & 1 & $\begin{array}{l}\text { Normal sella with } \\
\text { macrocephaly }\end{array}$ & $\begin{array}{l}\text { Platyspondyly } \\
\text { and middle } \\
\text { breaking }\end{array}$ & $\begin{array}{l}\text { Sloping of iliac } \\
\text { wings }\end{array}$ & $\begin{array}{l}\text { Proximal } \\
\text { pointing of } \\
\text { metacarpals }\end{array}$ & nil & $\begin{array}{l}\text { Epi- } \\
\text { metaphyseal } \\
\text { irregularity }\end{array}$ \\
\hline Turners & 1 & $\begin{array}{l}\text { Diffusely } \\
\text { decreased density }\end{array}$ & Nil & Nil & $\begin{array}{l}\text { Positive } \\
\text { metacarpal } \\
\text { sign }\end{array}$ & nil & nil \\
\hline Apert's & 1 & $\begin{array}{l}\text { Tower shaped } \\
\text { skull }\end{array}$ & Nil & Nil & $\begin{array}{l}\text { Pre-axial } \\
\text { syndactly }\end{array}$ & nil & nil \\
\hline Craniosynostosis & 1 & $\begin{array}{l}\text { Focally decreased } \\
\text { density } \\
\text { copper and } \\
\text { skull }\end{array}$ & Nil & Nil & nil & nil & nil \\
\hline Down's & 1 & Microcephaly & cardiomegaly & $\begin{array}{l}\text { Flaring of iliac } \\
\text { wings }\end{array}$ & nil & nil & nil \\
\hline Pfeiffer's & 1 & $\begin{array}{l}\text { Focally decreased } \\
\text { density, } \\
\text { scaphocephaly, } \\
\text { small posterior } \\
\text { fossa and bony } \\
\text { spiculations }\end{array}$ & Nil & Nil & nil & nil & nil \\
\hline
\end{tabular}

Table 3. Cross tabulation skull Xray vs whole skeletal survey

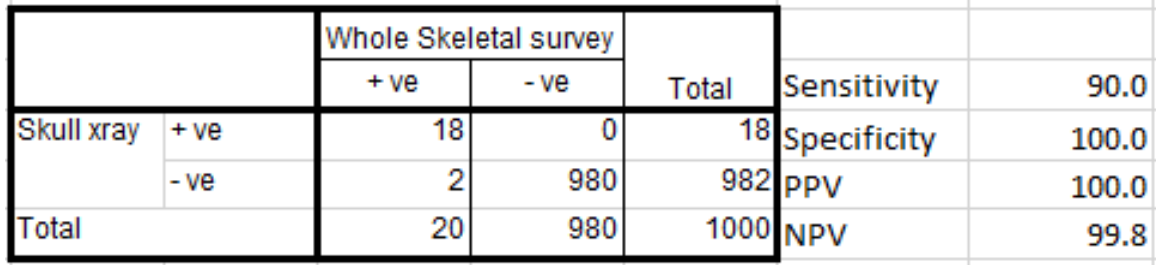

\section{Discussion}

Overall incidence of dysplasia and dysostoses in our study was 20 per 1000 in high risk group and this was supported by kulkarni et al 1995 study [4] where, children with high risk factors suffered from these disorders 10 to 20 times higher than normal children. Consanguinity (25\%) followed by advanced maternal age $>35(23 \%)$ are the major risk factors in our study, Fig.(1) and this was supported by kulkarni et al sudy in 1990[5] and the higher incidence of dysplasias (39.1/1000) was due to consanguineous history. 
Our classification of dysplasia and dysostoses was based on 2010 revision of the Nosology and Classification of Genetic Skeletal Disorders framed by the International Skeletal Dysplasia Society [1,6,7] and skull findings classification from Glass et al study in 2004. [2] Skull radiograph revealed findings in 18 cases, who also had findings in rest of the skeletal survey TABLE (2). Five patients had macrocephaly [2] out of which three turned out to be achondroplasia Fig.(3),because they had narrow skull base and narrow foramen magnum[1,2,8,9] and one with $\mathbf{J}$ shaped sella[1,10,11] turned out to be hurler's Fig.(4) and other one was morquio's disease.[1,11] Rest of the skeletal suvey of the same five patients had findings in appendicular skeleton and axial skeleton which supported the diagnosis. Other differentials of macrocephaly like alexander disease, canavan disease, sotos syndrome and tuberous sclerosis should be ruled out. [2]

One patient had microcephaly [2,12] and that turned out to be down's syndrome. Same patient had other findings like flaring of iliac wings and confirmed with genetic studies. Other differentials of microcephaly like fetal alcohol syndrome, TORCH syndrome, trisomy 13 and Rubinstein-Taybi syndrome should be ruled out. [2] Two patients had diffuse increase in density [2] of the skull, among them one had increased density in base of skull turned out to be osteopetrosis $[1,11,13]$ confirmed with other skeletal findings like bone within bone appearance and sandwich vertebrae Fig.(5). The other patient had increased skull density with wide open fontanelle, wormian bones, obtuse angle of mandible and turned out to be pyknodysostosis[1,11,13],patient also had acro-osteolysis in hand Fig.(6). Another patient had wormian bones with normal mandibular angle with absent clavicle and widened symphysis was cleidocranial dysplasia.

Two patients had diffuse decreased density of skull [2], one patient with platybasia and multiple appendicular skeleton fractures turned out to be osteogenesis imperfecta $[1,14,15]$ and another female patient with positive metacarpal sign had turner's syndrome[16,17], other differentials like hypophosphatasia \& menkes syndrome should be ruled out. Another two patients had focal decreased density of skull [2] and patients had other features like premature fusion of sutures and diagnosed as craniosynostosis [2,18,19] Fig.(7).one more patient had tower skull and diagnosed as apert's syndrome. TABLE (1)

Other findings like dolichocephalic skull in two patients had associated platyspondyly and abnormal epiphysis turned out to be spondyloepiphyseal dysplasia [1,11,20,21] and one patient had teeth abnormalities turned out to be chondroectodermal dysplasia [1,13,22], patient also had acromesomelia, postaxial syndactyly and pelvis abnormalities. only two patients had normal skull xray with stippled epiphyseal calcification and diagnosed as chondrodysplasia punctata. [1,11,13] Other conditions like hypochondroplasia, pseudoachondroplasia, spondylometaphyseal dysplasia also shows normal skull Xray.[1]

Skull Xray alone has $100 \%$ specificity and positive predictive value versus whole skeletal survey in diagnosis of dysplasia/dysostoses.TABLE (3) Brindhaban et al in 2005[3] conducted a study to estimate the radiation dose during whole skeletal survey and they found that the effective dose(E) values for whole skeletal survey in less than 1 year children was $150 \mu \mathrm{Sv}$ (mean) with maximum upto $260 \mu \mathrm{Sv}$. Whereas, for skull Xray the effective dose(E) values was $13 \mu \mathrm{Sv} \&$ maximum around $20 \mu \mathrm{Sv}$. This leads to significant increase in fatal malignancies risk by $10-30 /$ million and with multiple exposures the risk further increases. [3,23-26] So,the effective radiation dose can be decreased by taking skull Xray first and in cases where it reveals findings or conditions where there is strong clinical suspicion(even if skull xray is normal) like chondrodysplasia punctata, Pseudoachondroplasia, spondylometaphyseal dysplasia, then further radiological examination can be proceeded.

Limitations of this study includes small number of positive cases (many other dysplasias and dysostoses were not included in this study) and longer duration prospective studies needed to test this hypothesis.

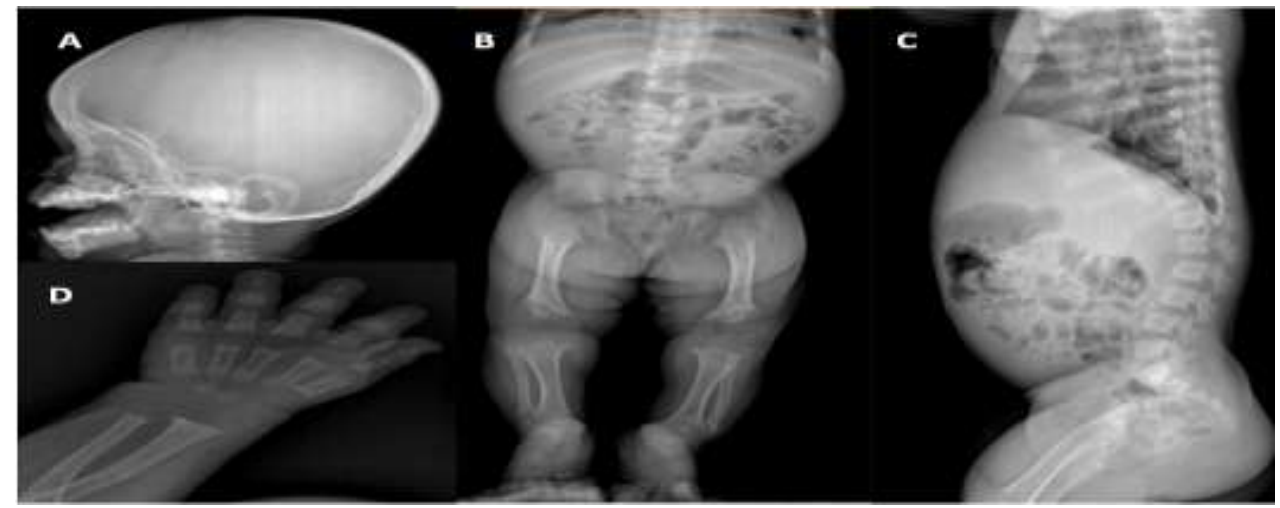

Figure 3 Achondroplasia. A) Skull Xray lateral view shows macrocephaly with narrowed skull base and foramen magnum, B) Pelvis with both lower limb (AP view) Xray shows narrow interpedicular distance in lower lumbar spine, champagne-glass appearance of pelvis, squaring of iliac wings, Rhizo-melic type of lower 
limb shortening with metaphyseal splaying,C)Dorsolumbar spine Xray lateral view shows bullet shaped vertebral body, D)Left hand Xray shows trident hand.

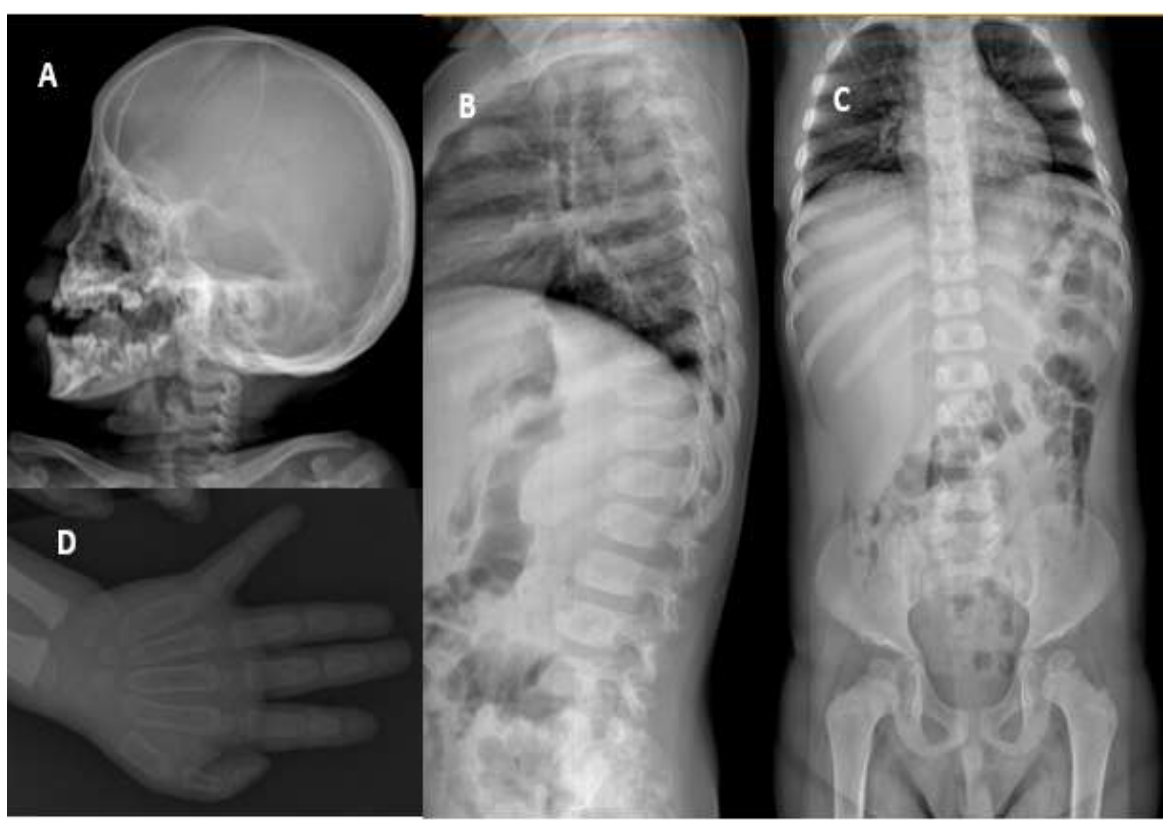

Figure 4 Hurler's disease. A) Skull Xray lateral view shows macrocephaly with J shaped sella, B) Dorsolumbar spine Xray lateral view shows antero inferior beaking in lumbar vertebrae, C) Xray dorsolumbar spine with pelvis (AP view) shows paddle shaped ribs (posterior ribs),Sloping of iliac wings with shallow acetabulae, D) left hand Xray shows proximal pointing of metacarpals.

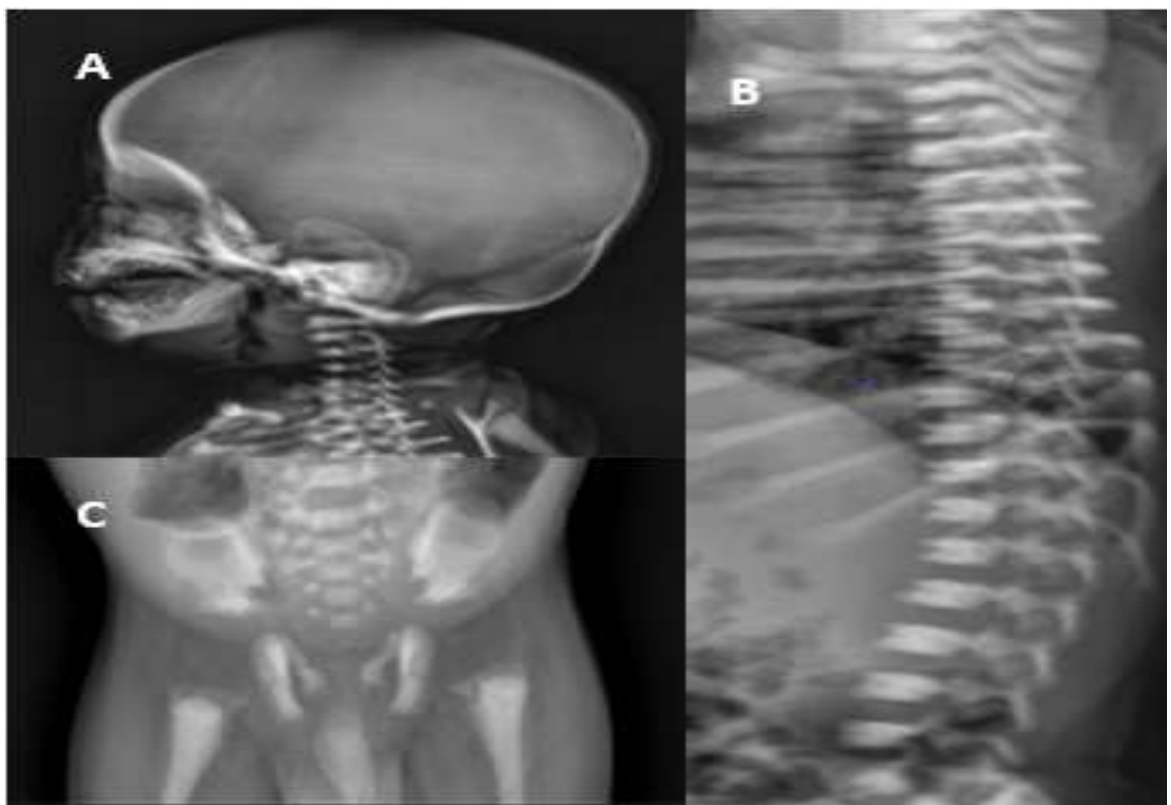

Figure 5 Osteopetrosis. A) Skull Xray lateral view shows diffusely increased density (in base of skull) B) Dorsolumbar spine Xray lateral view shows sandwich vertebrae, C) Pelvis Xray(AP view) shows bone within bone appearance. 


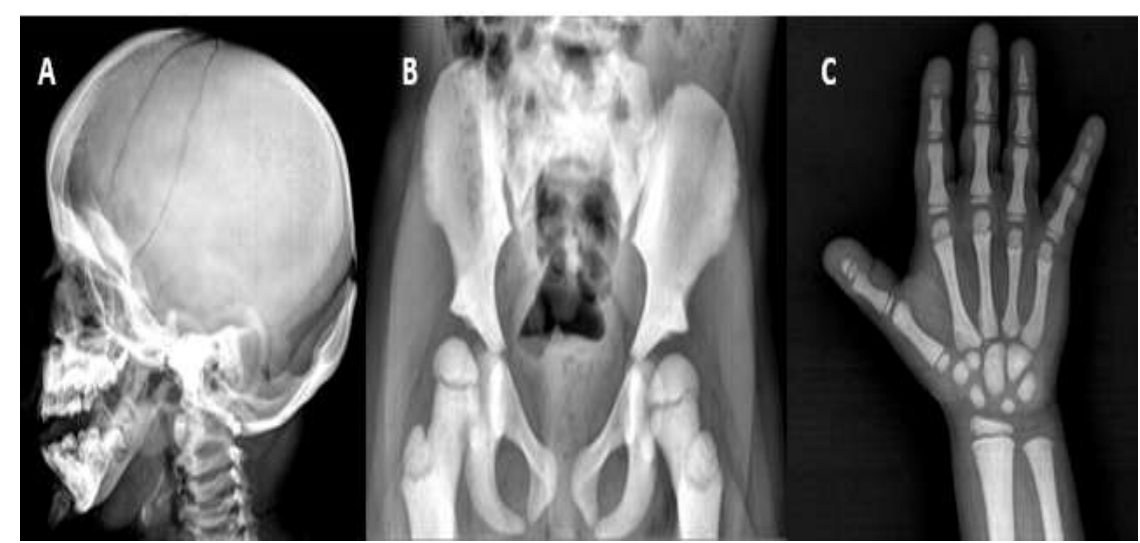

Figure 6 Pyknodystosis A) Skull Xray lateral view shows diffusely increased density, obtuse mandibular angle, wide open fontanelle and presence of wormian bones B) Xray pelvis (AP view) shows diffusely increased density with shallow acetabulae, C) )Left hand Xray shows diffusely increased density with acro-osteolysis .

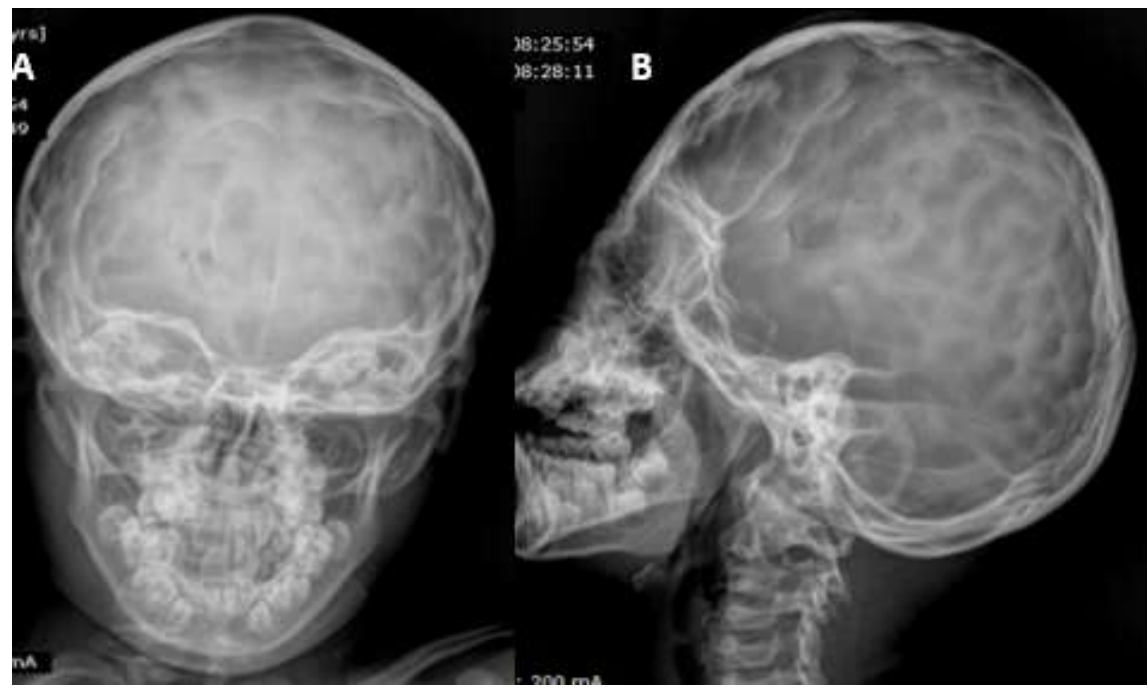

Figure 7 Craniosynostosis. A, B) Skull Xray AP and lateral view shows Focally decreased density with premature fusion of coronal and sagittal sutures and copper beaten skull.

\section{Working Algorithm Based On Our Cases And Findings}

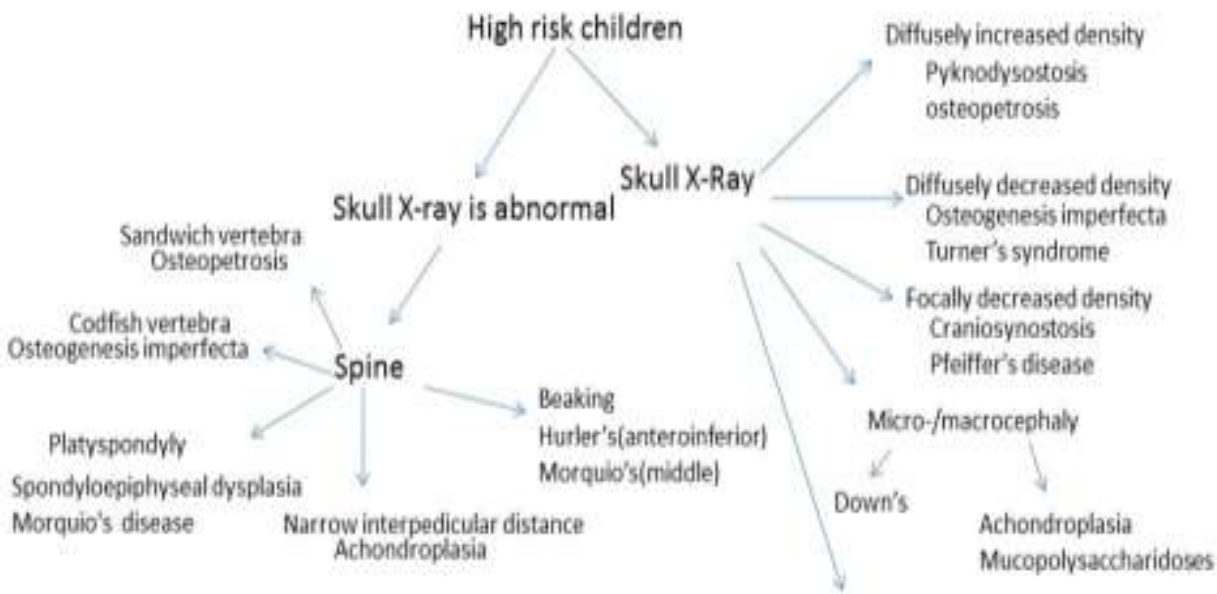

Others like craniosynostosis, wormian bones(cleidocranial

dysplasia,pyknodysostosis\}, obtuse mandibular

angle(Pyknodysostosis) and teeth

abnormalities(chondroectodermal dysplasia) 


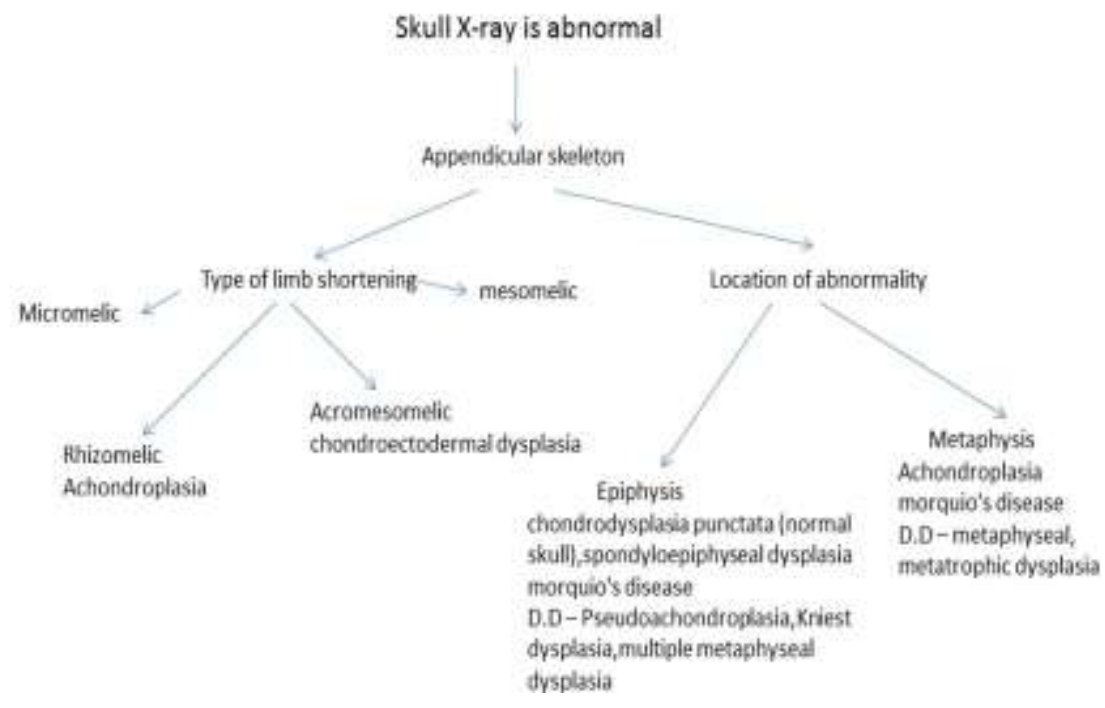

\section{Conclusion}

In High risk children, rather than doing whole skeletal survey as routine examination, skull Xray can be done initially as screening tool and in case of abnormal findings or strong clinical suspicion of few dysplasias with normal skull then the rest of the skeletal survey can be considered. This approach will reduce effective radiation(E) dose for those children who are undergoing repeated Xray exposures.

\section{References}

[1]. Panda A, Gamanagatti S, Jana M, Gupta AK, Skeletal dysplasias: A radiographic approach and review of common non-lethal skeletal dysplasias, World J Radiol, 6(10), 2014 Oct 28, 808-82.

[2]. Ronald B. J. Glass, Sandra K. Fernbach, Karen I. Norton, Paul S. Choi, and Thomas P. Naidich, The Infant Skull: A Vault of Information, RadioGraphics,24:2, 2004,507-522.

[3]. Brindhaban A1, Eze CU, Estimation of radiation dose during diagnostic X-ray examinations of newborn babies and 1-year-old infants, Med Princ Pract,15(4),2006,260-5.

[4]. Kulkarni ML,Samuel K, Bhagyavathi M, Sureshkumar C, Skeletal dysplasias in a hospital in southern India, Indian Pediatr,32(6), 1995, 657-65.

[5]. Kulkarni ML, Kurian M, Consanguinity and its effect on fetal growth and development. A South Indian Study, J Med Genet, 27, 1990, 348-353.

[6]. Warman ML, Cormier-Daire V et al, Nosology and classification of genetic skeletal disorders:2010 revision, Am J Med Genet A, 155A,2011,943-968.

[7]. Alanay Y, Lachman RS, A review of the principles of radiological assessment of skeletal dysplasias, J Clin Res Pediatr Endocrinol,3, 2011,163-178.

[8]. Horton WA, Rotter JI, Rimoin DL, Scott CI, Hall JG,Standard growth curves for achondroplasia, J Pediatr, 93,1978,435-438.

[9]. Steinbok P, Hall J, Flodmark O,Hydrocephalus in achondroplasia: the possible role of intracranial venous hypertension, $\mathrm{J}$ Neurosurg,71, 1989,42-48.

[10]. Lachman RS,Skeletal Dysplasias, Slovis TL,Caffey’s Pediatric Diagnostic Imaging. 11th ed,(Philadelphia: Mosby Elsevier, 2008) 2613-2671.

[11]. Tachdjian MO,Pediatric Orthopedics. 2nd ed,(Philadelphia:W B Saunders Co, 1990) 690-843.

[12]. Behrman RE, Kliegman RM, Jenson HB, Nelson textbook of pediatrics. 16th ed,(Philadelphia, Pa: Saunders, 2000$) 455-456$.

[13]. Spranger JW, Langer LO, Wiedemann HR,Bone Dysplasias:An Atlas of Constitutional disorders of Skeletal Development,(Philadelphia (PA): WB Saunders Co, 1974).

[14]. Sillence DO, Senn A, Danks DM, Genetic heterogeneity in osteogenesis imperfecta, J Med Genet,16, 1979,101-116.

[15]. Rauch F, Glorieux FH, Osteogenesis imperfecta, Lancet,363,2004,1377-1385.

[16]. Robinow M, Spisso K, Buschi AJ et-al,Turner syndrome: sonography showing fetal hydrops simulating hydramnios, AJR Am J Roentgenol,135 (4),1980, 846-8.

[17]. Gambino J, Caldwell B, Dietrich R et-al,Congenital disorders of sexual differentiation: MR findings,AJR Am J Roentgenol, 158 (2), 1992,363-7.

[18]. Benson ML, Oliverio PJ, Yue NC et-al, Primary craniosynostosis: imaging features, AJR Am J Roentgenol. 166 (3), $1996,697-703$.

[19]. Khanna PC, Thapa MM, Iyer RS, Prasad SS,Pictorial essay: The many faces of craniosynostosis, Indian J Radiol Imaging,21, 2011,49-56.

[20]. Amirfeyz R, Clark C, Gargan M,Spondyloepiphyseal dysplasia.Current Orthopaedics, 19,2005,309-313.

[21]. MacKenzie JJ, Fitzpatrick J, et-al, X-linked spondyloepiphyseal dysplasia: a clinical, radiological and molecular study of a large kindred, J Med Genet,33,1996,823-828.

[22]. Rudnik-Schöneborn S, Zerres K, et-al,Two Adult Patients with Ellis-van Creveld Syndrome Extending the Clinical Spectrum, Mol Syndromol,1,2011,301-306.

[23]. Cardillo I, Boal T, Einsiedel P,Patient dose from chest radiography in Victoria, Australas Phys Eng Sci Med,20,1996,92-101.

[24]. Boal T, Cardillo I, Einsiedel P,Paediatric dose from diagnostic radiology in Victoria, Australas Phys Eng Sci Med, $21,1998,57-67$.

[25]. Almen A, Mattson S, Dose distribution in children at chest radiography, Rad Prot Dosim,57,1995,463-467.

[26]. Schneider K, Evolution of quality assurance in paediatric radiology, Rad Prot Dosim,57,1995,119-123. 